\title{
ULAMA KEDAH AND TABAGSEL NETWORK IN 1900-1950
}

\section{Sehat Sultoni Dalimunthe ${ }^{1}$; Zainal Efendi Hasibuan²; Ali Amran ${ }^{3}$} IAIN Padangsidimpuan,

Email: lanawalakum@yahoo.co.id ${ }^{1}$, zainalefendihasibuah708@gmail.com²; amranhsbz@gmail.com ${ }^{3}$

Abstract

The Kedah and Tabagsel Ulama Network in 1900-1950 was important to be discussed considering that there were some scholars from Tabagsel who were studying in Kedah. After that, they proceed to Mecca. After they returned to Indonesia they established a pesantren. Among them, Sheikh Ahmad Daud (1891-1981), Muhammad Mukhtar Harahap, founder of the Padang Padang Lawas al-Mukhtariyah boarding school, Sheikh Abdul Qadir Mandily, and Sheikh Juneid Thola from Kotanopan. For education experts in Malaysia mention that since 1924-1945 there was a golden age of Islamic education in Kedah. Many Ulama in Kedah came from Patani because of security factors that were not conducive, so they migrated to Kedah. Later, after the Tabagsel ulemas came back and established Islamic boarding schools in their respective regions, they gave colors to Islamic education for the community.

Keyword: Ulama network, Kedah, Tabagsel, 1900-1950

$$
\begin{aligned}
& \text { ملخص } \\
& \text { كان من المهم مناقشة شبكة قدح وعلامة تبغسل للعلماء في الفترة 1900-1950 بالنظر إلى } \\
& \text { وجود بعض العلماء من تاباجسل الذين يدرسون في قدح. بعد ذلك يذهبون إلى مكة. بعد أن } \\
& \text { عادوا إلى إندونيسيا أسسوا بيزانترين. من بينهم ، الشيخ أحمد داود (1891-1981) ، و وُمَّمَّم } \\
& \text { مختار حراحب ، مؤسس مدرسة بادانغ بادانغ لاياس المختارية الداخلية ، والشيخ عبد القادر } \\
& \text { مانديلي ، والشيخ جونيد ثولا من كوتانوبان. لخبراء التعليم في ماليزيا يذكرون أنه منذ 1924- } \\
& 1945 \text { كان هناك عصر ذهبي للتعليم الإسلامي في قدح. جاء العديد من العلماء في قدح من }
\end{aligned}
$$

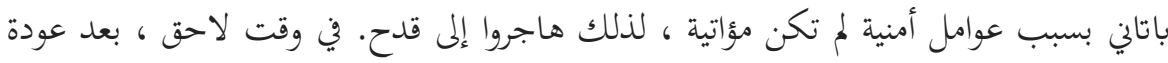

$$
\begin{aligned}
& \text { علماء تاباجسل وإنشاء المدارس الداخلية الإسلامية في مناطقهم ، أعطوا ألوانًا للتعليم الإسلامي } \\
& \text { للمجتمع. } \\
& \text { كلمة مفتاحية: شبكة العلماء ، قدح , تباغسل , عام 1900-1950 }
\end{aligned}
$$




\section{Fitrah \\ I Jurnal Kajian Ilmu-ilmu Keislaman \\ Vol. 6 No. 1 June 2020}

\section{INTRODUCTION}

If you look at the Southern Tapanuli scholars who used to live in a South Tapanuli Regency. Among them, Sheikh Abdul Qodir al-Mandili, Sheikh Thala Junaid, Sheikh Mushtafa Husein, Sheikh Ahmad Daud Siregar, Sheikh Mukhtar Sunge Dua, H. Abdul Rahman Dalimunthe, H. Abdul Rahim Dalimunthe, H. Yusuf Harahap Samaninggir, and so on. They generally denounce Islamic education in Kedah.

Islamic education in Kedah is important for the people of Tabagsel because the country is the closest door to the safest land route from North Sumatra, namely Medan to perform the pilgrimage to Mecca. Because learning directly to Mecca was excellent in those days. This was driven by the desire to gain knowledge from the original source, namely the city of Mecca. Another impetus, not many scholars who qualified in Tabagsel in the early 1900. For this reason, the opportunity to reach Mecca by the silk route, the door is from Kedah for the people of North Sumatra.

In the 1950s and above, the silk lane became deserted because sea transportation by machine ships was felt and believed by pilgrims to be safe and lighter, despite the challenge being the sea.

It is this background that attracts researchers to directly observe the learning places of the Tabagsel scholars in Kedah and also gather information from the Kedah community that allows them to still have knowledge about it. Also, look for data in government archive offices that store data from Kedah in 1900-1950. Looking at the characteristics of the relationship between scholars of Kedah and Tabagsel, this paper tries to describe two parts, namely the history of the relationship between tabagsel scholars and Kedah in 1900-1925 and 19251950.

\section{Ulama Kedah and Tabagsel Network in 1900-1925}

The South Tapanuli community consisting of Padangsidimpuan City, South Tapanuli Regency, Mandailing Natang Regency, Padang Lawas Regency, and North Padang Lawas Regency first embraced Islam as a result of the proactive part of the community'sefforts to interact with ulama in other areas which had earlier converted to Islam. The neighboring area of Tabagsel is now earlier Muslim and there is Islamic education or at least Islamic da'wah, in present-day West Sumatra and Riau. West Sumatra, more specifically Pasaman, 
where the famous ulama in the region are known as Tuanku Imam Bonjol and Tuanku RAO.In the Riau area, namely Sidalu-Dalu with the famous clericTuanku Tambusae.

Early Islam had come to North Sumatra now in the Barus area through Arab traders. However, it is believed there is no systematic preaching. After the Paderi army entered the Tabagsel region and the entire community was confirmed to have been Muslim. There was no religion before Islam in Tabagsel, but its belief was animism. Thus, Islamization to Tabagsel through the Paderi army. After the Islamic community of Tabagsel, it is not known that some of the Paderi soldiers living inTabagsel had a degree of ulema, apart from being limited to being Muslim and could teach basic Islamic teachings such as prayer. At first, the Tabagsel people began to seriously study Islam into Christmas from ulama who came from Arabia through Pasaman. The cleric who deliberately developed Islam at Christmas came by sea from Pasaman, Sheikh Abdul Fatah. The Islamic community in Mandailing Regency is nowpartly starting to study for Christmas. After learning they returned to the village to teach Islam.

From the above facts, the role of Islam in Tabagsel, West Sumatra is very important. The beginning of the entry of scholars into Christmas came from West Sumatra. Then the Paderi army disengaged the pros and cons of their goals, but the Islam of Tabagsel was thanks to the Paderi army. After the Islam of the Tabagsel community, relations to West Sumatra in learning still continued.

Islam entered Malaysia systematically and massively from Patani. This can be understood from the relics of many regional names in Kedah originating from Thailand. The analysis can be understood logically because there are people who are at war who are looking for security by moving. Likewise, the inhabitants of Yan in Kedah were known as Kampung Aceh, because the Acehnese were believed to have crossed from Aceh to Yan Kedah to avoid the Dutch invaders.

Since 1900, it is known that the people of Tabagsel know that there is an Islamic education center in Kedah. Seeing the sea distance between Medan and Kedah is quite close, some people began to cross to Kedah to study. In the early 1900s at Air Hitam (Ayer Hitam), a hip area of the Kedah sea stood a number of huts that were cared for by Kedah scholars. According to Prof. Dr. Khoo Key Kim, one of the well-known historians in Malaysia, Kedah, Kelantan, and Trengganu was the first country in Malaysia to accept Islam. 


\section{Fitrah \\ I Jurnal Kajian Ilmu-ilmu Keislaman \\ Vol. 6 No. 1 June 2020}

Kedah is important in the history of Tabagsel's Islamic education because this country is the closest entrance by sea to the Holy City of Mecca, the center of world Islamic education, and the dream of every Muslim to perform the pilgrimage. Through this Kedah, scholars of North Sumatra to Hajj travel by land. For this reason, traveling by land for the people of North Sumatra, including Nanggoro Aceh Darussalam, Kedah is the only place to go to Mecca. Actually through the sea route the Nanggro Aceh Darussalam community is closer to Patani, it's just that due to the security factor that is controlled by Syiam, Patani is not conducive to a place of learning for Muslims. For this reason, many Patani scholars came out of the country, including Kedah, a country that borders directly with Patani. For that reason too, the Nanggro Aceh Darusalam people studied Islam to Kedah and then to Mecca.

The appeal of Kedah as a destination for Islamic education with the pondok system in the early 1900s, especially for the people of North Sumatra, including Tabagsel and NAD, studied Islam while continuing the ideals of performing the pilgrimage.

The pilgrimage journey by land from Medan can pass through the port of Belawan to Kedahuan Air Hitam Kedah. From Kedah - Patani - Bangkok Cambodia - India - Pakistan - Iran - Iraq - Mecca. This trip is certainly not done continuously, but on the way stopover for a break-even suspected in Muslim areas such as Patani, India, Pakistan, Iran, and Iraq most likely they are the pilgrims to receive greetings and assistance like a traveler mandated by the Koran 'to be helped. Not demanding possibilities, they stayed for a while to look for life and provisions in an area.

Culture makes it easy for students and pilgrims, for example, it can be seen from the attitude of the people in Tanjung Pura Langkat, students in Babussalam from outside the area get $100 \%$ more than those who are not students. This is a good example of appreciation for students, so they can live. Seeing Kedah as a rice barn for the State of Malaysia, it is very possible if the Tabagsel ulemas used to study while working in this country as farmers were given free land by the community. They can also earn a living by working in the fields of the community and can also rent rice fields to work on. It may also be that they are living free of school and living expenses by teachers or those who have a cottage, but they must help the teachers to work in the fields. This latter model is still found in the pesantren traditions in North Padang Lawas Regency. 
Where the students in the rice season, especially during planting and harvesting, students are usually invited to help the work of their teachers in the fields.But usually, students are not given wages, only covered by eating and drinking and even smoking for men and other consumption. But there are students who do not pay school fees and teachers are also not paid. The teacher lives in farming. Even if there is a school fee, it is usually in the form of rice after harvest and that too is relatively small. After students pay school fees with rice, then those who have boarding schools share some of it with the teachers. That was the life of the pesantren in Kabupaten.

\section{Ulama Kedah and Tabgsel Network in 1925-1950}

Kedah in 1925-1950 historians calls the golden age of education at Kedah. At that time boarding schools thrived in Kedah and his students came from various countries in Malaysia and various regions in Indonesia, especially from North Sumatra, Aceh Darussalam, and Riau today.

The Tabagsel cleric lived in Kedah and his family and no longer returned to his hometown. These scholars include people who have interpreted the Qur'an. In addition to scholars, he is also a scientist who writes many books. In addition, he is also a politician. This scholar named Shaykh Abullah Abbas Nasution. He had set up a cottage in Bandar Darul Aman Kedah. He actively preached at the Masjid al-Fatih. This mosque is one of the best mosques in the Darul Aman Kedah area. Facilities are quite satisfying for the Congregation. Bathroom and toilet facilities can compensate for hotel level facilities.

Haji Abdullah Abbas Nasution is also a scholar who actively preaches and writes. According to Datu Wan Syamsuddin, Malaysian historian, Haji Abdullah Abbas Nasution was born in Langgar, Alor Star, Kedah on 1 Mai 1912. But according to his son Jamal Naser Nasution, his father was born in Medan. Haji Abdullah received a preliminary education rather than his father until he was 10 years old. After that, he entered the Langgar Malay School in 1920. In 1923, he continued his studies at the pondok (Arabic) school on Pisang Island and in Jitra, Kedah. In 1928, he continued his study at Pondok Tok Kenali in Kota Bharu, Kelantan, and then moved to study at Maahad Muhammadi, Kota Bharu until 1936. Finally, he studied at the Ahmadiyya Bunut Payong cottage, Kota Bharu from 1937 to 1940. After that, he returned to the pondok school on Pisang Island, Jitra as a teacher, and then moved to Pondok Haji Muhsin, Titi Besi, Head 


\section{Fitrah \\ $\exists$ Jurnal Kajian Ilmu-ilmu Keislaman \\ Vol. 6 No. 1 June 2020}

of the Boundary. At the end of 1940, Haji Abdullah Abbas Nasution opened a religious education school known as the Madrasah Ma'had Ehya Al-Ulum AdDiniah in Tanjung Pauh, Jitra. This madrasa teaches Islamic Education, Malay, Arabic, and English subjects. In 1940 until 1967, the Maahad Ehya Madrasah AIUlum Ad-Diniah had given birth to about 4000 students.

In addition to teaching, Haji Abdullah Abbas Nasution is also a scholar who actively preaches and writes books. He has started writing since the early 1930s. In 1933, Haji Abdullah became a writer in the local Kelantan newspaper, at that time he was still studying in Kota Bharu, Kelantan Pondok Tok Kenali. In the field of writing, Haji Abdullah often uses the pseudonym A.A. Pilpisani, AAN, and Ibn Arabi. This is perhaps the reason why he is not known by Tabagsel scholars.

His writings $\mathrm{H}$. Abdulah Abbas Nasution in the newspapers are often religious issues in the family column. He also writes in Singapore Newspapers and Penang. News that he had written about the story of a chicken thief, a fight, and a corpse.

Besides writing in the newspapers, H. Abdullah Abbas Nasution also translated Arabic books into Malay. Among his translated works, the book Tarbiah Al-ljtimaiah (social education), Tarbiah Al-Wataniah (Egyptian Political Science), and several other books. In addition to translating, he has also authored several books such as the History of Greater Malay which records the history of the Malays from the time of Sri Vijaya and the arrival of Islam to Southeast Asia. In 1940, H. Abdullah Abbas Nasution began the work of translating the Koran alKarim which was printed in 1959. He had also written an interpretation of the Koran. The commentary was completed in 8 years. In total, from 1933 to 1980, Haji Abdullah Abbas Nasution had written and translated about 100 books and articles on various topics. Most of his books deal with Islam, including culture and history. He also writes about the history of Southeast Asia. In addition, he also wrote a lineage and his family. Some scientific books such as Geography, Economics, a biography of his life, Political Science, Social Science, education, and others. Most of his works are written in thuluthic form and some are typed.

H. Abdullah Abbas Nasution is also active in the Kedah Ulama Association (PUK). Initially the Kedah Ulama Association (PUK), he was considered as a figure because he was served as a muddy Ma'had Ehya Al-Ulum 
Addiniah at Tanjung Pauh, Jitra, Kedah. As the founding figure of the PUK, H. Abdullah Abbas Nasution is known as a secretary.

As the secretary of the PUK, he succeeded in making the AD / ART of the union. The rule accommodates Indian clerics in Pulau Pinang. From January 1946 to 1949 he went to the Maktab Mahmud Alor Star, which later became a Kingdom school. In other words, H. Abdullah Abbas Nasution also became a teacher at a Royal school after Malaysia gained independence. His condition as going home in a Royal school became a problem for his status in the Kedah Ulama Association which was not a kingdom, as the Indonesian Ulema Council. PUK's view, free from Kingdom interference. For this problem, H. Abdulah Abbas Nasution was transferred to Madrasah At Taufikiah AI-Khairiah in Guar Cempedak which was freer from government intervention, because the madrasa was a public religious school that was not bound by government regulations. Around the 1950s, H. Abdullah Abbas Nasution was appointed as the PUK Chair in the field of education replacing Sheikh Abdul Halim Othman.

\section{CLOSING}

Barus, Bonjol, Si Dalu-Dalu, and Tanjung Pura have services for some Tabagsel people to get to know Islam individually. Next, Christmas became a deliberate area for introducing Islam through Sheikh Abdul Fatah. Tabagsel's Islamization services must of course be recognized by the services of Paderi's army regardless of their initial motivations. Serious and very meaningful Islamic education for Tabagsel scholars, Kedah is the one who plays a role.

In 1900-1925 there was a wave of Tabagsel clerics studying in Kedah who were still studying close to the sea and then they continued on to Mecca. In 19251950, Islamic education in Kedah had reached its peak. That is, if the Tabagsel scholars did not continue their education to Mecca, their knowledge was still very adequate. But the opportunity to perform the pilgrimage by land made the scholars generally continue their education to Mecca. 


\section{Fitrah \\ $\triangle$ Jurnal Kajian Ilmu-ilmu Keislaman \\ Vol. 6 No. 1 June 2020}

\section{REFERENCES}

Abdullah, Abdul Rahman, Islam dalam Sejarah Asia Tenggara Tradisional, Selangor: Pustaka Haji Abdul Majid, 2006.

Alam, Sutan Tinggi Barani Perkasa, Surat Tumbaga Holing 1, Medan: Mitra, 2012.

Aly, Mustafa dan Abdullah, Sejarah Pendidikan Islam di Indonesia, (Bandung: Pustaka Setia, 1998.

Arikunto, Suharsimi, Prosedur Penelitian,Jakarta: Rineka Cipta, 1996.

Azra, Azyumardi, Historiografi Islam Kontemporer: Wacana, Aktualitas, dan Aktor Sejarah, Jakarta: Gramedia, 2002.

--------, Jaringan Ulama Timur Tengah sdan Kepulauan Nusantara Abad XVII dan XVIII, Bandung: Mizan, 1998.

--------, Azyuramardi, Renaisans Islam di Asia Tenggara, Bandung: PT. Remaja Rosdakarya, 2006.

Badan Pusat Statistik, Tapanuli Selatan Dalam Angka 1999.

Bagir, Haidar, "Napas Cinda dari Hadramaut", Majalah Tempo, Minggu 12 Agustus 2012

--------, Islam dan Budaya Lokal, dalam 'Islam Nusantara; Dari Ushul Fiqh hingga Paham Kebangsaan”, Akhmad Sahal dan Munawir Aziz (Edt), Bandung, Mizan, 2016.

Biografi Ulama Kedah Darul Aman, Kedah: Lembaga Muzium Negeri Kedah Darulaman, 1996.

Dato, Muhammad Hassan, "Kerani Mohd Arshad, Al-Tarikh Salasilah Negeri Kedah, Kuala Lumpur : DBP, 1968.

Djajaningrat , P.A. Hoesein, "Islam di Indonesia," dalam Kenneth W. Morgan, Islam Jalan Lurus, terj. Abu Salamah dan Chaidir Anwar, (Jakarta: Pustaka Jaya, 1986. 
Erawadi, "Jaringan Keilmuan Antara Mandailing-Angkola dan Ulama Semenanjuang Melayu" dalam Prosiding Nadwah Ulama Nusantara (NUN) V, 9-10 Juni 2015.

Erawadi, "Pusat-Pusat Perkembangan Tarekat Naqsabandiyah di Tapanuli Bagian Selatan" dalam Miqat, Vol. XXXVIII. NO. 1 Januari-Juni 2014.

Guillot, Claude, dkk.,Barus Seribu Tahun Yang Lalu, Jakarta: KPG, 2008.

Haddad, Hasyim. Zaman Keemasan Islam di Kedah Sebelum Kemerdekaan.Kuala Lumpur, Dewan Bahasa dan Pustaka, 2015.

Huda, Nor, Islam Nusatanra: Sejarah sosial Intelektual Islam di Indonesia, Jokjakarta: al-Ruzz Media, 2007.

Hurgronje , C. Souck, “Arti Agama Islam bagi Penganutnya di Hindia belanda dalam Kumpulan Karangan Snouck Hurgronje, terj. Sutan Maimun dan rahayu S. Hidayat, Jakarta: INIS, 1994.

Institut Agama Islam Negeri, Sejarah Ulama-ulama Terkemuka di Sumatera Utara, Medan: 1975.

Jamaluddin, Wan.Sejarah Islam di Kedah. Dewan Bahasa dan Pustaka, 2016.

Majlis Kebudayaan Negeri Kedah Darul Aman, Dokumentasi Konvensyen Sejarah Negeri Kedah Darul Aman 111998.

Manti, Biltiser Bachtiar, dkk, “Konsep Pendidikan Modern Mahmud Yunus dan Kontribusinya Bagi Lembaga Pendidikan Islam di Indonesia, Jurnal Ta 'dibuna, Vol. 5 No 2, 2016.

Nasution, S., Metode Research, Jakarta: Bumi Aksara, 2003.

Parsadaan Marga Harahap Dohot Anakboruna, Horja: Adat Iistiadat Dalihan Natolu, Jakarta: Parsadaan Marga Harahap dohot Anakboruna, 1003.

Rukiati, Enung K., Sejarah Pendidikan Islam di Indonesia. Bandung: Pustaka Setia, 2006.

Sabtu, Mohd Supian, Tamadun Awal Lembah Bujang, Kuala Lumpur: Dewan Bahasa dan Pustaka, 2002. 


\section{Fitrah \\ $\triangle$ Jurnal Kajian Ilmu-ilmu Keislaman}

Vol. 6 No. 1 June 2020

Suryanegara, Ahmad Mansur, Menemukan Sejarah: Wacana Pergerakan Islam di Indonesia, Bandung: Mizan, 1998.

Yatim, Badri, Sejarah Peradaban Islam, Jakarta: RajaGrafindo Persada, 2011. 